\title{
Quiz-Enhanced Learning in Elementary School
}

\author{
Olivera Iskrenović-Momčilović \\ University of Novi Sad, Faculty of Education
}

\section{Abstract}

In modern teaching and new technological environment, a teacher should design activities that will stimulate students to actively participate in the process of acquiring knowledge. The use of quizzes in teaching creates a competitive spirit, develops creativity and accuracy in students, entrusts the activity and motivation of students in the process of acquiring knowledge. This paper examines the effectiveness of the Kahoot quiz in teaching science in the learning of basic concepts of relief in elementary school. The analysis has shown that there is a statistically significant difference in achievement among students who have studied in traditional ways and those who have used the Kahoot quiz. The obtained results are in a positive correlation with the mark in science and showing that there are no differences in achievement between boys and girls. It can be concluded that the quiz as an alternative way of learning has practical use in teaching, which enables cognitive, motivational, emotional and social development of students. Students experience solving the quiz as a game that positively influences the adoption and understanding of teaching material.

Key words: Kahoot; science; quiz; students; teaching

\section{Introduction}

Today, there are several web tools that are used in the realization of basic principles of teaching gymnastics such as scoring, levelling, competitive spirit, and rewarding (Lee \& Hammer, 2015). Regardless of whether these tools are used as a form of gym training or in the function of traditional testing of knowledge, examining students' opinions and attitudes, they allow the creation of quizzes, knowledge tests, and other forms of competitive spirit games. It should be emphasized that most of the quizzes are used as a teaching tool (McDaniel et al., 2012). 
A quiz is a form of a game where a competitor or group of participants tries to answer specific questions from different areas of knowledge accurately. It is a type of test and demonstration of knowledge which involves more students at the same time, competitive spirit and current results. With all this in mind, the quizzes correspond most closely to the principles of teaching gymnastics (Andrés et al., 2015). Research on quizzes has shown that such tools are not a trend or a thrill, but a real technological advancement that can change teaching and make it more dynamic and interesting (Cohen \& Sasson, 2016). Depending on the web tools, they can work individually or in teams. With a good and thoughtful selection of multiple-choice questions, a good choice of distractors (wrong answers) in particular, higher levels of knowledge can be checked in this way.

Today, more and more quizzes are tested on students' performance when used as an isolated assessment tool and when they are integrated in the teaching process. Salas-Morera et al. (2012) have shown that quizzes have a positive impact on students' academic performance over five years of online quiz experimentation. Students support a new teaching method, which differs from routine lectures because it is innovative, interesting, interactive and informative (Devi, 2014). Johnson and Kiviniemi (2009) found that the use of quizzes motivates students to participate in classroom discussions and improve performance compared to other ways of checking knowledge. Berrais (2014) points out that more than $90 \%$ of students praised the use of Moodle quizzes because they helped them learn mathematics and prepare for final exams.

Cook and Babon (2017) emphasize the importance of active learning within higher education institutions to help students develop higher-level thinking and link new knowledge with the existing. They suggest the use of weekly quizzes as an effective mechanism for encouraging active learning. On the other hand, Ferrándiz et al. (2016) describe the learning experience with Socrative, an available free application that allows students to answer teachers' short, true/false or multiple-choice questions posed during each class using their smartphones.

Having a multitude of free web-based tools that offer a click-through assessment, it is safe to say that those tools that are visually appealing are far more popular concerning colours and shapes used in the work environment, as well as effects and clearly visible player profiles of each student. These tools mostly differ in the way the game is played, or whether there is a teacher or learner over the game (Derera \& Naude, 2014). The most popular tools for quizzes are Kahoot, Quizible and Socrative.

Kahoot is a simple and interactive tool for creating quizzes, polls or launching a discussion with the aim of more efficient learning. The Kahoot quiz consists of an arbitrary number of questions that students can answer for a limited time. Upon completion of the quiz, a teacher receives a report containing the name of each student and their answers. For the realization of the quiz, the classroom should have a video connection with a teacher's computer, and students should have smartphones, tablets or computers connected to the Internet. 
In the Kahoot quiz, questions of multiple choice can be created (with one of four answers being the correct one), and a photo or film can be inserted into the text of the question. Making quizzes in Kahoot is very simple and proved to be very interesting to children. Children develop a motive and a desire for the best possible success and victory, i.e. students develop a competitive spirit (Bicen \& Kocakoyun, 2018). With the help of quizzes children memorize easily and quickly, even the tiniest details within a subject which remain in their memory for a long time (Atherton, 2018). This is a form where learners acquire permanent knowledge of given topics through a game.

Smith and Brauer (2018) investigated the application of the Kahoot quiz in conducting the Thermodynamics course, which is one of the most challenging courses in the mechanical engineering curriculum. There are many elements in a Kahoot quiz that can increase student motivation, including competition with classmates and included music. Aktekin et al. (2018) proposed the use of Kahoot quiz at the end of each anatomy lecture during two semesters. The advantages of this kind of work are greater presence and participation, and more focused and engaged students in a class. The results suggest that game-based response systems can be used in basic medical school courses. The subject of research is to examine the effectiveness of the Kahoot quiz application in the teaching the subject science. The research aimed to examine whether there are differences in the quality of learning basic concepts from the subject science in a traditional way and using the Kahoot quiz. The research objectives are:

- determine whether there are differences in terms of students' quality of knowledge

- determine whether group affiliation affects students' levels of knowledge

- determine if there is a relationship between the mark in science and the quality of the students' knowledge

- determine if there are differences in the quality of knowledge between boys and girls

\section{Methods}

The research sample consisted of 106 students of the third grade of elementary school from the Republic of Serbia, in the 2017/2018 school year.This size of the sample is small, so it can affect the stability and confidence of the results. Of the total number of students, $45 \%$ were boys and 55\% were girls. Students were divided randomly into two groups of 54 participants: control (C) and experimental (E). First, both groups did an initial science test, and then a teaching theme Relief was implemented within each group of students. Group $\mathrm{C}$ learned basic concepts of relief in a traditional way using a PowerPoint presentation. At the end of the day, they solved a conventional test

Group E also learned basic concepts of relief through a PowerPoint presentation, but at the end of the day took a Kahoot quiz. The questions, along with the offered answers, were displayed on the video beam. Students did not see the offered answers on their mobile devices, but the fields of different colours with different symbols. They chose that field which they considered to be the correct answer. After the expiration of the time, the teacher gave the correct answer with an explanation. 
After completing the teaching theme Relief, both groups of students took a final test without prior notification. The initial and final test were the same. The aim of this test was to examine the effectiveness of the Kahoot quiz application in relation to traditional teaching during the course of the same teaching theme. The test was created on the basis of Bloom's taxonomy (Krathwohl, 2002). Although Bloom's taxonomy has six categories in the cognitive area, nine questions on the test were organizedinto three levels:

- level of recognition - contains three questions:

1. Complete the sentence -

A flat area at an altitude above 200 meters is

2. Circle the letter in front of the correct answer.

All the plains, recesses and elevations on Earth's surface are:
a) unevenness
b) beauty
c) relief
d) land

3. Determine which statement is correct (Yes) or incorrect (No).
a) The plain is lower up to $200 \mathrm{~m}$ above sea level.
Yes No
b) The gorge is where the river springs.
Yes No

- level of reproduction - contains three questions:

1. Multiple association

Associate terms with appropriate description:

hill elevation more than 500 meters above sea level

mountain elevation with an altitude of 200 to 500 meters

hill elevation with altitude up to 200 meters

2. Exclusive association

Associate terms with appropriate description:

river bed recess filled with flowing water

gorge recess between steep slopes of high mountains

basin deep and narrow recesses that the river intersects

canyon

3. Write the correct names

The highest mountain in Serbia is

- level of analysis - contains three questions

1. Images

Write what the parts of the hill are called

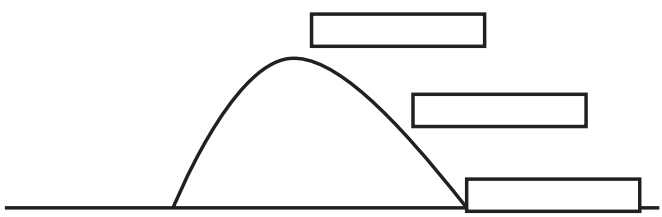




\section{Rebuses}

Moving the letters gives the names of some forms of relief njonkazinialinadolisurak

\section{Explanations}

How is the lowland different from the plateau?

The aforementioned classification of the level of quality of knowledge was used in the research because it can effectively perceive the implementation of the set goal and tasks of the research.

ANOVA 2x2 results show the differences between the $\mathrm{E}$ and $\mathrm{C}$ groups in the quality of knowledge.Variables are categories of knowledge: recognition, reproduction and analysis. In addition, $\mathrm{F}$ tests for individual variables as recognition, reproduction and analysis have been performed. The results showed on which dependent variables the change occurred and what the change was. The effect size can be defined as any statistical indicator, which determines the degree to which the result obtained on the sample differs from the expectations (Sun et al., 2010). There are a number of different effect sizes, the most common of which are eta squared, Cohen's $d$ and Cohen's $f$ (Pallant, 2011). Eta squared $\left(\varepsilon^{2}\right)$ represents the proportion of variance of the dependent variable that is explained by the independent variable (Pallant, 2011). It can have values in the range 0 to 1 . The guidelines for the interpretation of the eta square (Cohen, 1988), when evaluating the research, which includes the comparison of groups, are given in Table 1.

Table 1

Cohen's recommendation for interpretation of the eta square

\begin{tabular}{lll}
\hline Effect size & Eta squared & Explained variance \\
\hline Small & up to 0.05 & $\begin{array}{l}\text { up to } 5 \% \text { of explained variance } \\
\text { Middle }\end{array}$ \\
from 0.06 to 0.13 & $\begin{array}{l}\text { from } 6 \% \text { to } 13 \% \text { of explained } \\
\text { variance }\end{array}$ \\
Large & over 0.13 & over $13 \%$ of explained variance \\
\hline
\end{tabular}

\section{Results and discussion}

a) Changes in the quality of students' knowledge

During the research, the progress of each group in relation to initial testing and the progress between $\mathrm{E}$ and $\mathrm{C}$ group was examined. ANOVA $2 \times 2$ results (Table 2) show the positive influence of Kahoot quiz on all categories of knowledge, although both groups showed some improvements between the initial and the final test. The obtained results indicate that E group achieved statistically better results in the final test compared to the $\mathrm{C}$ group. The greatest progress was observed in the analysis $(\mathrm{F}=32.35 ; \mathrm{p}<0.01)$ and reproduction $(\mathrm{F}=27.14 ; \mathrm{p}<0.01)$. All of this can be easily seen in Figure 1. where the largest line slope is observed, which shows the progress of the knowledge to the level of analysis, and then the line related to the reproduction. 
Table 2

Changes in the quality of students' knowledge

\begin{tabular}{lcccccc}
\hline & & \multicolumn{2}{c}{ Initial test } & \multicolumn{2}{c}{ Final test } \\
\hline Variable & Group & $\mathrm{M}$ & $\mathrm{SD}$ & $\mathrm{M}$ & $\mathrm{SD}$ & $\mathrm{F}$ \\
\hline Recognition & $\mathrm{C}$ & 4.589 & 1.110 & 3.444 & 1.518 & \\
& $\mathrm{E}$ & 4.569 & 1.361 & 4.708 & 1.320 & $11.15^{*}$ \\
Reproduction & $\mathrm{C}$ & 3.861 & 1.190 & 4.180 & 1.440 & \\
& $\mathrm{E}$ & 3.847 & 1.459 & 4.972 & 1.020 & $27.14^{*}$ \\
Analysis & $\mathrm{C}$ & 1.638 & 1.356 & 2.097 & 1.575 & \\
& $\mathrm{E}$ & 1.555 & 1.643 & 3.888 & 1.939 & $32.35^{*}$ \\
\hline
\end{tabular}

Tags: M- arithmetic mean; SD - standard deviation; F - ANOVA 2x2; ${ }^{*}$ p $<0.01$

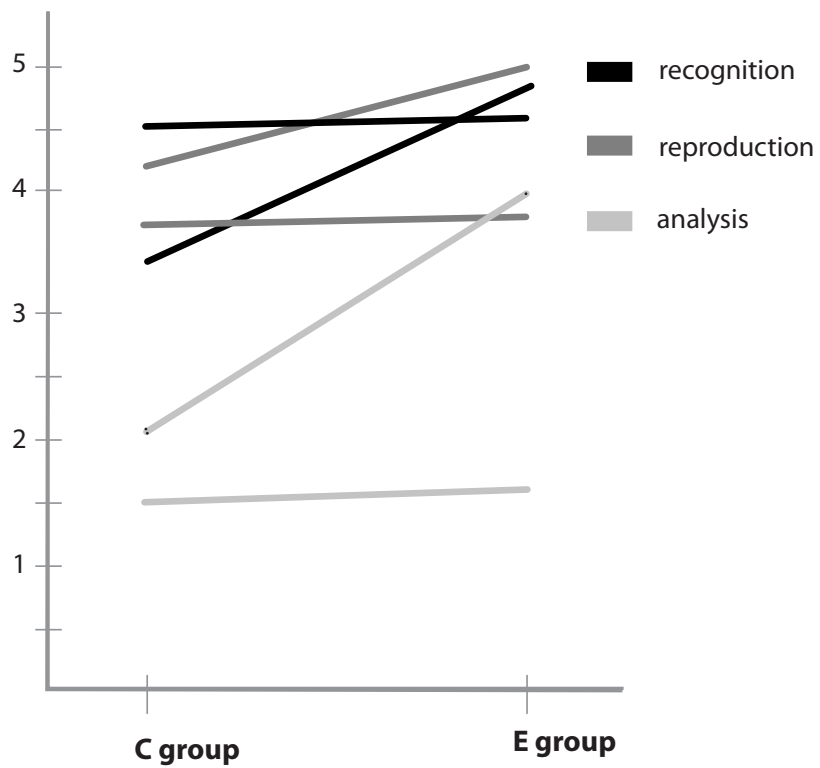

Figure 1. Changes in knowledge categories: recognition, reproduction and analysis

Recognition: In the initial testing, $\mathrm{E}$ and $\mathrm{C}$ groups were equated by results on the basis of knowledge recognition. At the end of the test, there was little progress in the $\mathrm{E}$ group and a significant drop in the $\mathrm{C}$ group score. There is a difference in the success of the $\mathrm{E}$ and $\mathrm{C}$ group at the final test (1.264 points).

Reproduction: In the initial testing, the $\mathrm{E}$ and $\mathrm{C}$, the groups were equated by the results on the subtlety of knowledge reproduction. C group was very small, while the E group made more progress (1.125 points). The E group was more successful than the $\mathrm{C}$ group in the final test (the difference was 0.792 points).

Analysis: In the initial testing, E and C groups were balanced by results on the subtest of knowledge analysis, but in the final test, there were large differences (2.333 points). Both groups advanced in relation to initial testing, with the progress of the $\mathrm{C}$ group smaller than the E group. 
Salas-Morera et al. (2012) came to the same conclusions. Ares et al. (2018) have shown that the Kahoot quiz improves student memory and facilitates the learning process itself. The learning results obtained are better, and the effectiveness of the Kahoot quiz depends on the frequency of application. Frequent use of Kahoot quiz allows students to enjoy fun play, gauge their progress, and improve their learning (Pennebaker et al., 2013). Tóth et al. (2019) show that students who took part in more Kahoot quizzes tend to score a higher exam mark. With the help of the Kahoot quiz, students memorize the content learned more and apply what they have learned more easily (Atherton, 2018).

Licorish et al. (2018) found that the Kahoot quiz enriched the quality of student learning by influencing student dynamics, engagement, motivation and experience. Teachers find that the Kahoot quiz is not only useful for enhancing students' knowledge but also creates an atmosphere of fun and enjoyment in the classroom (Sabandar et al., 2018). In addition, this quiz is also able to raise motivation among students to score better results in learning and initiate a healthy competition and positive communication among the students (Bicen \& Kocakoyun, 2018).

b) The effect of the group affiliation on the quality of knowledge

During the research, the effect of the group affiliation on changes in the knowledge of recognition, reproduction, analysis and the total score was analysed (Table 3). The results showed that group affiliation had affected all levels of knowledge and the total score. The biggest change occurred in the total score. This result suggests that the differences between the $\mathrm{E}$ and $\mathrm{C}$ groups in the overall knowledge are statistically significant. Based on the eta squared $\left(\varepsilon^{2}=0.410\right)$, it is concluded that $41 \%$ of the variability can be explained or predicted based on the group's membership. The resulting effect is large, according to Cohen's interpretation (Table 1).

Table 3

The effect of the group affiliation on the quality of knowledge

\begin{tabular}{lccccc}
\hline Variable & Group & $\mathrm{M}$ & $\mathrm{F}$ & $\mathrm{p}$ & $\varepsilon^{2}$ \\
\hline Recognition & $\mathrm{C}$ & 3.444 & 22.787 & 0.033 & 0.142 \\
& $\mathrm{E}$ & 4.708 & & & \\
Reproduction & $\mathrm{C}$ & 4.180 & 12.366 & 0.025 & 0.078 \\
& $\mathrm{E}$ & 4.972 & & & \\
Analysis & $\mathrm{C}$ & 2.097 & 46.685 & 0.027 & 0.237 \\
& $\mathrm{E}$ & 3.888 & & & \\
Total score & $\mathrm{C}$ & 3.240 & 89.937 & 0.011 & 0.410 \\
& $\mathrm{E}$ & 4.523 & & & \\
\hline
\end{tabular}

Tags: $M$ - arithmetic mean; $p$ - significance of the $F$ test; $\varepsilon^{2}$ - eta squared

The differences between the two groups of participants are statistically significant in all categories of knowledge: recognition, reproduction and analysis. Based on the eta squared, it is concluded that the effect on the categories of analysis $(23.7 \%$ of variability) and recognition (14.2\% of variability) is significant, while the effect on 
the category of reproduction ( $7.8 \%$ of variability) is moderate. This result confirms the shift in the quality of E group knowledge to higher levels of knowledge. There are statistically significant differences in the quality of knowledge in students who have adopted the basic concepts of relief in the traditional way and students who have adopted the same terms with the Kahoot quiz.

Literature review revealed that certain studies reported that the Kahoot quiz used for assessment purposes improved student knowledge (Göksün \& Gürsoy, 2019). Iwamoto et al. (2017) found that the students who used the Kahoot quiz had a significant difference in the test scores compared to the students who did not use the Kahoot quiz. Also, Tsihouridis et al. (2018) point out that students who used the Kahoot quiz had slightly better results than those who did not. Wichadee and Pattanapichet (2018) showed statistically significant differences in learning performance and student motivation when using the Kahoot quiz.

c) The effect of the mark in science on the quality of knowledge

As part of the research, we wanted to determine whether the change in knowledge is influenced by the mark in science. Statistically significant differences were obtained, which show that the mark in subject science influences the change in the overall score and on the subtest of the analysis. The values of the eta squared (Table 4) show that the impact of the mark on changes in the total knowledge is small (5.6\% of the variability), and secondary in the knowledge analysis ( $8.1 \%$ variability). This means that with students who had more marks, the quality of the overall knowledge and knowledge of the analysis was improved. For other knowledge categories, statistically significant differences were not obtained, so there is no correlation between the mark and change in recognition and reproduction knowledge.

Table 4

The effect of the in subject science on the quality of knowledge

\begin{tabular}{lccccc}
\hline Variable & Group & $\mathrm{M}$ & $\mathrm{F}$ & $\mathrm{p}$ & $\varepsilon^{2}$ \\
\hline Recognition & $\mathrm{C}$ & 3.444 & & & \\
& $\mathrm{E}$ & 4.708 & 2.905 & 0.088 & 0.019 \\
Reproduction & $\mathrm{C}$ & 4.180 & & & \\
\multirow{2}{*}{ Analysis } & $\mathrm{E}$ & 4.972 & 1.046 & 0.303 & 0.007 \\
& $\mathrm{C}$ & 2.097 & & & \\
Total score & $\mathrm{E}$ & 3.888 & 12.904 & 0.001 & 0.081 \\
& $\mathrm{C}$ & 3.240 & & & \\
& $\mathrm{E}$ & 4.523 & 7.987 & 0.004 & 0.056 \\
\hline
\end{tabular}

Tags: $\mathrm{M}$ - arithmetic mean; $\mathrm{p}$ - significance of the $\mathrm{F}$ test; $\varepsilon^{2}$ - eta squared

The results obtained by examining the correlation of the mark in science and the success on the initial and final test are given in Table 5. The mark in science correlates with all levels of knowledge in initial and final testing. Based on the values of the correlation coefficient, it is concluded that the connection is positive, but weak or moderate (final testing - analysis 0.513 and total score of 0.598 ). The difference in 
scores between initial and final testing was calculated by excluding the initial test results from the students' scores on the final test. The resulting difference is about the progress of students in the final testing. It was found that the science mark correlates positively but only with the progress in the knowledge of analysis and in the overall score.

Table 5

Correlation between the knowledge and the mark in science

\begin{tabular}{lcccc}
\hline Testing & Recognition & Reproduction & Analysis & Total score \\
\hline Initial & $0.351^{*}$ & $0.391^{*}$ & $0.254^{*}$ & $0.462^{*}$ \\
Final & $0.449^{*}$ & $0.369^{*}$ & $0.513^{*}$ & $0.598^{*}$ \\
Difference & 0.098 & -0.022 & 0.159 & 0.132 \\
\hline
\end{tabular}

Tags: * $-p<0.01$

Assessment should take into account knowledge, work habits, ability to apply acquired knowledge in practice, advocacy, interest in teaching subjects, subjective possibilities and objective conditions in which a student learns (Nicholas, 2015). If the estimates were based on the valorisation of the mentioned components, their correlation with success on the normative tests of knowledge would be high. However, in practice, it is different, as evidenced by the results obtained.

Contemporary didactics does not extend an absolute advantage to a formative assessment over the normative one, but the tendencies are that the dominant assessment, based on the mutual comparison of students according to the level of overcoming the tasks envisaged, is equal in significance to criterion assessment which is the basis in the programming standards and defined competencies. Therefore, normative assessment is the establishment of standards that should be the basis for monitoring the development of students individually and defining the criteria for grading and self-assessment of students (Gojkov, 2009).

In educational systems where the tradition of using standardized knowledge tests is developed, there are problems because there are differences between common school grades and results in tests of knowledge (Duckworth et al., 2012). The correlations between them range from 0.62 to 0.66 . One of the explanations is that objective tests of educational attainment measure the competencies needed in the academic context and beyond, while for high grades in school it is sufficient to meet the demands of teachers and programs (Šarčević \& Vasić, 2014).

d) The effect of gender on the quality of knowledge

The study shows that there are no statistically significant differences at any level of knowledge, nor in the overall score (Table 6). It turns out that the changes in the knowledge of boys and girls are equal and that they do not affect them. This confirms that the gender of the student does not affect the change in the quality of students' knowledge in science. 
Table 6

The effect of gender on the quality of knowledge

\begin{tabular}{lccccc}
\hline Variable & Group & $\mathrm{M}$ & $\mathrm{F}$ & $\mathrm{p}$ & $\varepsilon^{2}$ \\
\hline Recognition & $\mathrm{C}$ & 3.444 & & & \\
& $\mathrm{E}$ & 4.708 & 2.611 & 0.107 & 0.017 \\
Reproduction & $\mathrm{C}$ & 4.180 & & & \\
& $\mathrm{E}$ & 4.972 & 0.069 & 0.791 & 0.001 \\
Analysis & $\mathrm{C}$ & 2.097 & & & \\
& $\mathrm{E}$ & 3.888 & 1.269 & 0.266 & 0.008 \\
Total score & $\mathrm{C}$ & 3.240 & & & \\
& $\mathrm{E}$ & 4.523 & 3.588 & 0.059 & 0.024 \\
\hline
\end{tabular}

Tags: $\mathrm{M}$ - arithmetic mean; $\mathrm{p}$ - significance of the $\mathrm{F}$ test; $\varepsilon^{2}$ - eta squared

Early research (Brković, 1994) shows that gender affects achievement, that it does not act in isolation from other factors, and that there are differences in content adoption in students of different sexes depending on the subject. Recent research indicates that there are no significant differences in achievement among boys and girls. Both boys and girls are equally successful and unsuccessful in school, which depends exclusively on other factors and not on gender (Simić-Vukomanović et al., 2012).

However, today there is research to the contrary arguing that there are differences in school achievement between boys and girls. Most studies have shown that girls outperform boys in school achievement and in most school subjects (Krneta, 2000). Classical explanations of such outcomes went in the direction of personality traits and motivation for learning particular subjects (Steinmayr \& Spinath, 2008). Other authors have sought an explanation for the differences in the different cognitive abilities of girls and boys (Babarović et al., 2010).

\section{Conclusion}

Kahoot is a simple and intuitive web-based quiz tool where students can test their knowledge and reaction speed in an attractive and fun way. It fosters a competitive spirit in students, and thus increases the student's motivation. The paper analyzes the application of the Kahoot quiz in teaching science, in learning the basic concepts of relief. The analysis showed that students who used the Kahoot quiz had greater achievement results compared to students taught in the traditional way. The implementation of the Kahoot quiz helped the students to show better knowledge at the level of recognition, reproduction and analysis. Their total knowledge has become greater, and of better quality.

The paper concludes that knowledge levels are positively correlated with assessment in science. The impact of the assessment is moderate at the level of recognition and reproduction, and weak at the level of analysis and overall knowledge. This confirms that students' prior knowledge influences the adoption of new emerging content. The results obtained showed that there were no differences in achievement between 
boys and girls. Both boys and girls were equally successful at the level of recognition, reproduction and analysis.

\section{References}

Aktekin, N.C., Çelebi, H., \& Aktekin, M. (2018). Let's Kahoot! anatomy. International Journal Morphology,36(2),716-721. https://doi.org/10.4067/S0717-95022018000200716

Andrés, B., Sanchis, R., \& Poler, P. (2015). Quiz game applications to review the concepts learnt in class: An application at the university context. Proceedings of the INTED2015 Conference (pp. 5054-5062), Madrid, Spain.

Ares, A.M., Bernal, J., Nozal, M.J., Sánchez, F.J., \& Bernal, J. (2018). Results of the use of Kahoot! gamification tool in a course of Chemistry. Proceedings of 4th International Conference on Higher Education Advances (pp. 1215-1222), Valencia, Spain. https://doi. org/10.4995/HEAD18.2018.8179

Atherton, P. (2018). More than just a quiz: how Kahoot! can help trainee teachers understand the learning process. Teacher Education Advancement Network Journal, 10(2), 29-39.

Babarović, T., Burušić. J., \& Šakić, M. (2010). Psihosocijalne i obrazovne odrednice školskog uspjeha učenika osnovnih škola: dosezi dosadašnjih istraživanja. Suvremena psihologija, 13(2), 235-256.

Berrais, A. (2014).Using online Moodle quizzes to support the teaching of mathematics to foundation engineering students. Proceedings of the Engineering Leaders Conference (pp. 1-5), Doha, Qatar.

Bicen, H., \& Kocakoyun, S. (2018). Perceptions of students for gamification approach: Kahoot as a case study. iJET, 13(2), 72-93. https://doi.org/10.3991/ijet.v13i02.7467

Brković, A. (1994). Uticajuspehaineuspehanaličnostučenika. Užice: Učiteljskifakultet.

Cohen, D.,\&Sasson I. (2016). Online quizzes in a virtual learning environment as a tool for formative assessment. Journal of Technology and Science Education, 6(3), 188-208.

Cohen, J. (1988). Statistical power analysis for the behavioral sciences (2nd ed.). Hillside: Lawrence Erlbaum Associates.

Cook, B.R., \& Babon, A. (2017). Active learning through online quizzes: better learning and less (busy) work. Journal of Geography in Higher Education. 41(1), 24-38. https://doi.org/ $\underline{10.1080 / 03098265.2016 .1185772}$

Derera, E., \& Naude, M. (2014). Unannounced quizzes: A teaching and learning initiative that enhances academic performance and lecture attendance in large undergraduate classes. Mediterranean Journal of Social Sciences, 5(20), 1193-1202. https://doi.org/10.5901/ miss.2014.v5n20p1193

Devi, K. (2014). Quiz as an innovative approach in teaching community medicine to medical students. National Journal of Community Medicine, 5(2),182-185.

Duckworth, A.L., Quinn, P.D., \& Tsukayama, E. (2012). What no child left behind leaves behind: The roles of IQ and self-control in predicting standardized achievement test scores and report card grades. Journal of Educational Psychology, 104(2), 439-451. https:// doi.org/10.1037/a0026280 
Ferrándiz, E., Puentes, C., Moreno, P.J., \& Flores, E. (2016). Engaging and assessing students through their electronic devices and real time quizzes. Multidisciplinary Journal for Education, Social and Technological Sciences, 3(2), 173-184. https://doi.org/10.4995/muse.2016.6375

Gojkov, G. (2009). Dokimologija. Visoka škola strukovnih studija za obrazovanje vaspitača Mihailo Palov.

Göksün, O.D., \& Gürsoy, G. (2019). Comparing success and engagement in gamified learning experiences via Kahoot and Quizizz. Computers \& Education, 135, 15-29. https://doi. org/10.1016/j.compedu.2019.02.015

Iwamoto, D.H., Hargis, J., Taitano, E.J., \&Vuong, K. (2017). Analyzing the efficacy of the testing effect using Kahoot! on student performance. Turkish Online Journal of Distance Education, 18(2), 80-93. https://doi.org/10.17718/tojde.306561

Johnson, B.C., \& Kiviniemi, M.T. (2009). The effect of online chapter quizzes on exam performance in an undergraduate social psychology course. Teaching of Psychology, 36, 33-37. https://doi.org/10.1080/00986280802528972

Krathwohl, D.R. (2002). A revision of Bloom's Taxonomy: An overview. Theory and practice, 41(4), 212-218. https://doi.org/10.1207/s15430421tip4104 2

Krneta, Lj. (2000). Faktori školskog uspjeha. Banjaluka kompani.

Lee, J., \& Hammer, J. (2015). Gamification in education: What, how, why bother? Academic Exchange Quarterly, 15(2), 1-5.

Licorish, S.A., Owen, H.E., Daniel, B., \& Gorge, K. L. (2018). Students' perception of Kahoot!'s influence on teaching and learning. Research and Practice in Technology Enhanced Learning 13, 9-32. https://doi.org/10.1186/s41039-018-0078-8

McDaniel, M.A., Wildman, K.M., \& Anderson, J.L. (2012). Using quizzes to enhance summativeassessment performance in a web-based class: An experimental study. Journal of Applied Research in Memory and Cognition, 1(1), 18-26.

Nicholas, M. (2015). Student knowledge: Curriculum, assessment and reporting. Journal of Educational Enquiry, 14(3), 1-16.

Pallant, J. (2011). SPSS priručnik za preživljavanje. Mikroknjiga.

Pennebaker J.W., Gosling S.D., \& Ferrell, J.D. (2013). Daily online testing in large classes: Boosting college performance while reducing gaps. PLoS ONE, 8(11), 1-6. https://doi. org/10.1371/journal.pone.0079774

Sabandar, G.N.C., Supit, N. R., \& Surzana, H.T.E. (2018). Kahoot!: Bring the fun Into the classroom!. Indonesian Journal of Informatics Education, 2(2), 127-134. https://doi. org/10.20961/ijie.v2i2.26244

Salas-Morera, L., Arauzo-Azofra, A., \& García-Hernández, L. (2012). Analysis of online quizzes as a teaching and assesment tool. Journal of Technology and Science Education, 2(1), 39-45. https://doi.org/10.3926/jotse.30

Simić-Vukomanović, I., Đukić-Dejanović, S., Đonović, N. \& Borovčanin, M. (2012). Psihomedicinski i socijalni činioci školskog uspeha. Engrami, 34(1), 45-57.

Smith, A., \& Brauer, S. (2018). Use of Kahoot! game for increased student motivation and understanding in a thermodynamics course. ASEE Southeastern Section Conference, Florida, USA. 
Steinmayr, R., \& Spinath, B. (2008). Sex differences in school achievement: What are the roles of personality and achievement motivation. European Journal of Personality, 22(3),185209. https://doi.org/10.1002/per.676

Sun, S. S., Pan, W., \& Wang, L.L. (2010). A comprehensive review of effect size reporting and interpreting practices in Academic Journals in Education and Psychology. Journal of Educational Psychology, 102, 989-1004. https://doi.org/10.1037/a0019507

Šarčević, D., \&Vasić, A. (2014). Sociodemografski i psihološki korelati školskog uspeha. Primenjena psihologija.7(3), 401-427. https://doi.org/10.19090/pp.2014.3.401-427

Tóth, Á., Lógó, P., \& Lógó, E. (2019). The effect of the Kahoot quiz on the student's results in the exam. Periodica Polytechnica Social and Management Sciences, 27(2), 173-179. https:// doi.org/10.3311/PPso.12464

Tsihouridis, C., Vavougios, D., \& Ioannidis, G. (2018). Assessing the learning process playing with Kahoot - a study with upper secondary school pupils learning electrical circuits. Proceedings of 20th International Conference on Interactive Collaborative Learning (pp. 11081118), Budapest, Hungary. https://doi.org/10.1007/978-3-319-73210-7 70

Wichadee, S., \& Pattanapichet, F. (2018). Enhancement of performance and motivation through application of digital games in an English language class.Teaching English with Technology, 18(1), 77-92.

\section{Olivera Iskrenovic-Momcilovic}

Faculty of Education

University of Novi Sad

Podgorička 4, 25101 Sombor, Serbia

oljkaisk@yahoo.com 


\section{Učenje u osnovnoj školi potpomognuto kvizovima}

\section{Sadržaj}

U suvremenom poučavanju okruženom novom tehnologijom učitelj bi morao osmisliti aktivnosti koje će potaknuti učenike na aktivno sudjelovanje u procesu usvajanja znanja. Korištenje kvizova u poučavanju razvija kompetitivni duh, kreativnost $i$ točnost kod učenika, osigurava aktivnost $i$ motivaciju učenika u procesu usvajanja znanja. Ovaj rad proučava učinkovitost Kahoot kviza u poučavanju nastavnoga predmeta Priroda i društvo kod učenja osnovnih pojmova reljefa u osnovnoj školi. Analiza je pokazala da postoji statistički značajna razlika u postignuću kod učenika koji su učili na klasične načine i onih koji su se u učenju koristili Kahoot kvizom. Dobiveni rezultati u pozitivnoj su korelaciji s ocjenom iz predmeta Priroda i društvo i pokazuju da ne postoje razlike u postignuću između dječaka i djevojčica. Može se zaključiti da kviz, kao alternativan način učenja, ima praktičnu primjenu u poučavanju koja omogućuje kognitivni, motivacijski, emocionalni i društveni razvoj učenika. Učenici percipiraju rješavanje kviza kao igru koja pozitivno utječe na usvajanje i razumijevanje nastavnoga sadržaja.

Ključne riječi: Kahoot, kviz, Priroda i društvo, poučavanje, učenici

\section{Uvod}

U današnje vrijeme postoji nekoliko mrežnih alata koji se koriste u ostvarivanju osnovnih principa poučavanja gimnastike poput bodovanja, poravnavanja, kompetitivnost duha i nagrađivanja (Lee i Hammer, 2015). Neovisno o tome koriste li se ovi alati kao oblici gimnastičkoga vježbanja ili u funkciji klasičnih oblika provjere znanja ili ispitivanja mišljenja i stavova učenika, oni omogućuju stvaranje kvizova, testova znanja i drugih kompetitivnih igara. Ipak, moramo naglasiti da se većina kvizova koristi kao alat za poučavanje (McDaniel i sur., 2012).

Kviz je vrsta igre u kojoj suparnik ili skupina sudionika pokušava točno odgovoriti na određeno pitanje iz različitih područja znanja. To je vrsta testa i pokazatelj znanja koje uključuje više učenika u isto vrijeme, stvara kompetitivni duh i daje trenutačne rezultate. Imajući to u vidu, kvizovi se gotovo u cijelosti podudaraju s principima poučavanja gimnastike (Andrés i sur., 2015). Istraživanja o kvizovima pokazala su da ti alati nisu samo trendovi ili užitci, nego istinski tehnologijski napredak koji može promijeniti poučavanje na način da ono postane dinamičnije i interesantnije (Cohen 
i Sasson, 2016). Ovisno o mrežnom alatu, kvizovi se mogu rješavati pojedinačno ili u timovima. S dobrim i osmišljenim odabirom pitanja višestrukoga izbora, posebice dobrim izborom distraktora (pogrešnih odgovora), mogu se testirati i više razine znanja.

Danas se sve više kvizova koristi za testiranje učenikovih postignuća kada se koristi kao alat za vrednovanje i kada je integriran u proces poučavanja. Salas-Morera i sur. (2012) pokazali su da kvizovi imaju pozitivan učinak na učenička postignuća tijekom pet godina eksperimentiranja s online kvizovima. Učenici podržavaju ovu metodu poučavanja koja se razlikuje od uobičajenih predavanja jer je inovativna, interesantna, interaktivna i informativna (Devi, 2014). Johnson i Kiviniemi (2009) ustanovili su da korištenje kvizova motivira učenike na sudjelovanje u raspravama i unaprjeđuje postignuća u odnosu na druge oblike provjere znanja. Berrais (2014) ukazuje na to da više od $90 \%$ učenika pohvaljuje korištenje Moodle kvizova jer im je to pomoglo $\mathrm{u}$ učenju matematike i u pripremama za završne ispite.

Cook i Babon (2017) ističu važnost aktivnoga učenja unutar institucija visokoga obrazovanja kako bi pomogli studentima razviti više razine razmišljanja te povezati novo znanje s već postojećim. Oni predlažu korištenje tjednih kvizova kao učinkoviti mehanizam za poticanje aktivnoga učenja. S druge strane, Ferrándiz i sur. (2016) opisuju iskustvo učenja s alatom Socrative, besplatno dostupnom aplikacijom koja omogućuje studentima da odgovore na nastavnikova kratka pitanja poput točno/netočno ili pitanja višestrukoga izbora tijekom svakog nastavnoga sata koristeći pametne telefone.

S obzirom na monogobrojnost besplatnih mrežnih alata koji nude klik vrednovanje, sigurno je reći da su oni vizualno privlačniji alati puno popularniji s obzirom na boje i oblike koji se koriste u radnom okruženju kao i efekti i dobro uočljivi profili svakog studenta. Ovi se alati uglavnom razlikuju u načinu igranja ili upravlja li igrom nastavnik ili učenik (Derera i Naude, 2014). Najpopularniji alati za izradu kvizova su Kahoot, Quizible i Socrative.

Kahoot je jednostavan interaktivni alat za izradu kvizova, anketa ili za pokretanja rasprava s ciljem učinkovitijega učenja. Kahoot kviz sastoji se od proizvoljnoga broja pitanja na koja učenici mogu odgovoriti u određenom periodu. Po završetku kviza, nastavnik dobije izvješće s imenom učenika i odgovore. Za realizaciju kviza, razredno odjeljenje trebalo bi biti opremljeno $s$ videopriključkom na računalu, a učenici bi trebali imati pametne telefone, tablete ili računala s internetskom vezom.

Kahoot kviz može sadržavati pitanja višestrukoga izbora (gdje je jedno od ponuđenih četiri odgovora točan odgovor), a u tekst pitanja može se uvrstiti fotografija ili film. Izrada kvizova u Kahoot programu vrlo je jednostavna te se pokazala zanimljiva djeci. Djeca razviju motiv i želju za najboljim mogućim rezultatom i pobjedom, točnije djeca razviju kompetitivni duh (Bicen i Kocakoyun, 2018). Uz pomoć kvizova djeca brže i lakše pamte čak i najmanje detalje unutar predmeta što u njihovom sjećanju ostaje duže vrijeme (Atherton, 2018). To je oblik u kojem učenici usvajaju trajno znanje sadržaja kroz igru. 
Smith i Brauer (2018) istraživali su primjenu Kahoot kviza u nastavi Termodinamike koji je jedan od najizazovnijih kolegija iz kurikula strojarstva. Mnogi elementi Kahoot kviza mogu potaknuti motivaciju učenika, primjerice kompetitivnost $\mathrm{s}$ vršnjacima $\mathrm{u}$ razredu i uključivanje glazbe. Aktekin i sur. (2018) predložili su korištenje Kahoot kviza na kraju svakog predavanja iz anatomije tijekom dva semestra. Prednosti ovoga načina rada su veća prisutnost i sudjelovanje studenata te fokusirani i angažirani studenti u nastavi. Rezultati sugeriraju da se sustav odgovaranja zasnovan na igri može koristiti $\mathrm{u}$ temeljnim kolegijima studija medicine.

Predmet istraživanja je proučavanje učinkovitosti Kahoot kviz-aplikacije u poučavanju predmeta Priroda i društvo. Cilj istraživanja bio je istražiti postojanje razlika u kvaliteti učenja osnovnih pojmova iz predmeta Priroda i društvo na tradicionalan način i korištenjem Kahoot kviza. Ciljevi istraživanja bili su:

- odrediti postojanje razlika s obzirom na kvalitetu znanja učenika

- odrediti utječe li pripadnost grupi na razine znanja učenika

- odrediti postojanje odnosa između konačne ocjene iz predmeta Priroda i društvo i kvalitete znanja učenika

- odrediti postojanje razlika u kvaliteti znanja između dječaka i djevojčica.

\section{Metode}

Uzorak ispitanika sastojao se od 106 učenika trećih razreda osnovne škole u Republici Srbiji, a provedeno je u školskoj godini 2017./2018. Veličina ovoga uzorka je mala i stoga može utjecati na stabilnost i pouzdanost rezultata. Od ukupnoga broja učenika $45 \%$ su bili dječaci, a $55 \%$ djevojčice. Učenici su bili nasumično podijeljeni u dvije skupine od 54 ispitanika: kontrolna (C) i eksperimentalna (E). Obje skupine bile su podvrgnute inicijalnom testu iz predmeta Priroda i društvo, a potom je sa svakom skupinom obrađena tema reljefa. Skupina $C$ učila je osnovne pojmove reljefa na tradicionalan način koristeći PowerPoint prezentaciju. Na kraju dana, učenici su riješili klasičan oblik testa.

Skupna E također je učila osnovne pojmove reljefa koristeći PowerPoint prezentaciju, ali su na kraju dana umjesto testa imali Kahoot kviz. Pitanja kao i ponuđeni odgovori prikazani su pomoću projektora. Učenici nisu vidjeli ponuđene odgovore na pametnim telefonima, nego su vidjeli različita polja boja s različitim simbolima. Učenici su odabirali ona polja koja su smatrali točnim odgovorima. Nakon isteka vremena, učitelj je ponudio točne odgovore s objašnjenjima.

Nakon obrade teme Reljef, obje skupine učenika imale su završni test bez najave. Inicijalni i završni testovi bili su identični. Cilj ovoga testa bio je proučiti učinkovitost primjene Kahoot kviz-aplikacije u odnosu na klasični oblik poučavanja iste nastavne teme. Test je izrađen po principima Bloomove taksonomije (Krathwohl, 2002). Iako Bloomova taksonomija ima šest kategorija u kognitivnoj domeni, devet pitanja iz testa uvršteno je u tri razine: 
- Razina prepoznavanja - sadrži tri pitanja

4. Dopuni rečenice

Ravna površina na visini iznad 200 metara je

5. Zaokruži slovo ispred točnog odgovora

Sve ravnice, udubljenja i povišenja na Zemljinoj površini su:
a) nejednakosti
b) ljepote
c) reljef
d) zemlja

6. Odredi koja je od ponuđenih tvrdnji točna ( $\mathrm{Da}$ ) ili netočna (Ne)

a) Ravnica je niža od 200 m iznad razine mora. $\quad \mathrm{Da} \quad \mathrm{Ne}$

b) Klanac je mjesto gdje izvire rijeka. $\mathrm{Da} \mathrm{Ne}$

- Razina reprodukcije - sadrži tri pitanja:

4. Višestruko povezivanje

Poveži pojmove sodgovarajućim opisom:

brdo povišenje više od 500 metara iznad razine mora

planina povišenje s visinom od 200 do 500 metara

brdo povišenjes visinom do 200 metara

5. Isključivo povezivanje

Poveži pojmove sodgovarajućim opisom:

korito rijeke udubljenje ispunjeno tekućom vodom

klanac udubljenje izmedu strmih litica visokih planina

sliv duboko i usko udubljenje koje presijeca rijeka

kanjon

6. Napiši točne nazive

Najviša planina u Srbiji je

- Razina analize - sadrži tri pitanja

4. Slike

Napiši nazive za tri dijela brijega

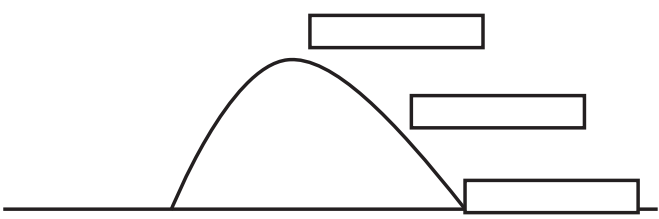

\section{Rebusi}

Pomičući slova dobit ćeš nazive za neke oblike reljefa

njonka zinia linado lisurak

6. Objašnjenja

Kako se nizina razlikuje od visoravni?

Prethodno spomenuta klasifikacija razine kvalitete znanja korištena je u ovome istraživanju jer može učinkovito uvidjeti primjenu postavljenih ciljeva i zadaća istraživanja. 
Rezultati ANOVA 2 x 2 ukazuju na razlike između E i C skupine u kvaliteti znanja. Varijable su kategorije znanja: prepoznavanje, reprodukcija i analiza. Povrh toga, proveden je i F test za pojedinačne varijable poput prepoznavanja, reprodukcije i analize. Rezultati su pokazali na kojoj se zavisnoj varijabli dogodila promjena i koja je to promjena bila. Veličina učinka može se definirati kao bilo koji statistički pokazatelj koji određuje stupanj do kojega se dobiveni rezultati iz uzorka razlikuju od očekivanih (Sun i sur., 2010). Postoje mnogobrojne različite veličine učinka, a najuobičajenije su eta na kvadrat, Cohenov d i Cohenov $\mathrm{f}$ (Pallant, 2011). Eta na kvadrat $\left(\varepsilon^{2}\right)$ predstavlja udio odstupanja zavisne varijable koja se objašnjava nezavisnom varijablom (Pallant, 2011). Može imati vrijednosti u rasponu od 0 do 1 . Smjernice za interpretaciju eta na kvadrat (Cohen, 1988) za procjenu istraživanja, a koje sadrže usporedbu skupina, prikazane su u Tablici 1.

Tablica 1.

\section{Rezultati i diskusija}

e) Promjene u kvaliteti znanja učenika

Za vrijeme istraživanja, ispitan je napredak svake skupine u odnosu na inicijalno testiranje te napredak između skupine E i C. Rezultati ANOVA 2 × 2 (Tablica 2) pokazuju pozitivan utjecaj Kahoot kviza na sve kategorije znanja iako su obje skupine pokazale napredak od inicijalnoga do finalnoga testa. Dobiveni rezultati ukazuju na to da je skupina $\mathrm{E}$ ostvarila statistički bolje rezultate u konačnom testu u odnosu na skupinu C. Najveći napredak uočen je kod razine analize $(F=32,35 ; \mathrm{p}<0,01)$ i reprodukcije $(\mathrm{F}=27,14 ; \mathrm{p}<0,01)$. Sve se to može vidjeti iz prikaza 1 gdje je uočena najveća linija zakrivljenosti koja ukazuje na napredak u znanju na razini analize te na liniji zakrivljenosti koja predstavlja reprodukciju.

Tablica 2.

Prikaz 1.

Prepoznavanje: $\mathrm{U}$ inicijalnom testiranju, skupine $\mathrm{E}$ i C imale su jednake rezultate $\mathrm{u}$ području prepoznavanja. U završnom testiranju, uočen je mali napredak kod skupine E i značajan pad u rezultatima skupine C. Postoji razlika u uspješnosti rješavanja završnoga testa u skupini E i C (1,264 bodova).

Reprodukcija: U inicijalnom testiranju, skupine E i C imale su jednake rezultate kod vještine reprodukcija. Skupina $\mathrm{C}$ imala je mali napredak dok je skupina $\mathrm{E}$ imala nešto veći napredak ( 1,125 bodova). Skupina $\mathrm{E}$ bila je uspješnija od skupine $\mathrm{C}$ u završnom testiranju (razlika je bila 0,792 bodova).

Analiza: $\mathrm{U}$ inicijalnom testiranju, skupine $\mathrm{E}$ i $\mathrm{C}$ bile su ravnomjerne $\mathrm{u}$ rezultatu na podtestu znanja analize, no u završnom testu uočena je velika razlika (2,333 bodova). Obje skupine pokazale su napredak u odnosu na inicijalno testiranje iako je kod skupine $\mathrm{C}$ napredak bio manji nego kod skupine $\mathrm{E}$. 
Salas-Morera i sur. (2012) došli su do istih zaključaka. Ares i sur. (2018) pokazali su da Kahoot kviz poboljšava pamćenje učenika i potiče proces učenja. Rezultati učenja su bolji, a učinkovitost Kahoot kviza ovisi o učestalosti primjene. Češće korištenje Kahoot kviza omogućuje učenicima da uživaju u igri, izmjere napredak i poboljšaju svoje učenje (Pennebaker i sur.,2013). Tóth i sur. (2019) pokazali su da učenici koji su češće sudjelovali u rješavanju Kahoot kvizova bili skloni boljim rezultatima na testovima. Uz pomoć Kahoot kviza učenici su bolje pamtili naučeni sadržaj te su isti lakše primjenjivali (Atherton, 2018).

Licorish i sur. (2018) otkrili su da je Kahoot kviz obogatio kvalitetu učenja tako da je utjecao na dinamiku, uključenost, motivaciju i iskustvo učenika. Učitelji smatraju da Kahoot kviz nije samo koristan za poboljšanje znanja učenika, nego da stvara atmosferu zabave i užitka u razredu (Sabandar i sur., 2018). Nadalje, ovaj kviz također može podići motivaciju među učenicima da ostvare bolje rezultate učenja te pokrenuti zdravu konkurenciju i pozitivnu komunikaciju među učenicima (Bicen i Kocakoyun, 2018).

f) Utjecaj pripadnosti skupini na kvalitetu znanja

Tijekom istraživanja, analiziran je utjecaj pripadnosti skupini na promjene u znanju - prepoznavanja, reprodukcije i analize, kao i ukupan rezultat (Tablica 3). Rezultati su pokazali da pripadnost skupini ima učinka na sve tri razine znanja te na ukupan rezultat. Najveća promjena uočena je kod ukupnoga rezultata. Ovaj rezultat ukazuje na to da su razlike između skupine $\mathrm{E}$ i skupine $\mathrm{C}$ u sveukupnom znanju statistički značajne. Na osnovi eta na kvadrat testa $\left(\varepsilon^{2}=0,410\right)$, zaključuje se da se $41 \%$ odstupanja može objasniti ili pretpostaviti na osnovi pripadnosti skupini. Prema Cohenovoj interpretaciji (vidi Tablicu 1) učinak je velik.

\section{Tablica 1.}

Razlike između dvije skupine ispitanika statistički su značajne u svim kategorijama znanja: prepoznavanje, reprodukcija i analiza. Na osnovi eta na kvadrat testa zaključuje se da je učinak na kategoriju analize (23,7 \% odstupanja) i prepoznavanja (14,2 \% odstupanja) značajan dok je srednja vrijednost učinka na kategoriju reprodukcija $(7,8$ $\%$ odstupanja). Ovaj rezultat potvrđuje pomak u kvaliteti znanja skupine E prema većoj kvaliteti znanja. Postoje statistički značajne razlike u kvaliteti znanja učenika usvajanjem osnovnih pojmova iz nastavne teme Reljef na tradicionalan način i onih koji su iste pojmove usvojili korištenjem Kahoot kviza.

Pregled literature otkrio je da su neka istraživanja pokazala da korištenje Kahoot kviza za potrebe vrednovanja poboljšala znanje učenika (Göksün i Gürsoy, 2019). Iwamoto i sur. (2017) ustanovili su da studenti koji su koristili Kahoot kviz imali značajne razlike u uspjehu na ispitima u usporedbi sa studentima koji nisu koristili Kahoot kviz. Nadalje, Tsihouridis i sur. (2018) ukazali su na to da su studenti koji su koristili Kahoot kviz imali nešto bolje rezultate od onih koji ga nisu koristili. Wichadee i Pattanapichet (2018) pokazali su postojanje statistički značajne razlike u postignuću i motivaciji učenika kada su koristili Kahoot kviz. 
g) Utjecaj ocjene iz predmeta Priroda i društvo na kvalitetu znanja

Dio ovoga istraživanja pokušalo je odrediti utječe li ocjena iz predmeta Priroda i društvo na promjenu u znanju. Dobivene su statistički značajne razlike koje ukazuju na to da ocjena iz predmeta Priroda i društvo utječe na promjenu u ukupnom rezultatu na podtestu analize. Vrijednosti eta na kvadrat testa (Tablica 4) pokazuju da je učinak ocjene na promjene u ukupnom znanju vrlo mali (5,6 \% odstupanja) a sekundaran u znanju - analize ( $8,1 \%$ odstupanja). To znači da je kod učenika koji su imali više ocjene, kvaliteta ukupnoga znanja i znanje razine analize bila poboljšana. Za ostale kategorije znanja nisu dobivene statistički značajne razlike, pa ne postoji korelacija između ocjene i promjene u znanju prepoznavanja i reprodukcije.

Tablica 4.

Rezultati dobiveni analizom korelacije ocjene iz predmeta Priroda i društvo i uspjeha na inicijalnom i završnom testu prikazani su u Tablici 5. Ocjena iz predmeta Priroda i društvo korelira sa svim razinama znanja u inicijalnom i završnom testu. Na osnovi vrijednosti koeficijenta korelacije, zaključujemo da je povezanost pozitivna, ali slaba ili umjerena (završno testiranje - analiza 0,513 i ukupni rezultat 0,598). Razlika u rezultatima inicijalnoga i završnoga testa dobivena je izostavljanjem inicijalnoga testa iz rezultata učenika na završnom testu. Dobivena razlika odnosi se na napredak učenika u završnom testu. Otkriveno je da ocjena iz predmeta Priroda i društvo pozitivno korelira, ali samo kod napretka u znanju na razini analize i u cjelokupnom rezultatu.

Tablica 5.

Vrednovanje znanja trebalo bi uzeti u obzir znanje, radne navike, sposobnost primjene znanja u praksi, posredovanje, interes za nastavni predmet, subjektivne mogućnosti i objektivne uvjete u kojima učenik uči (Nicholas, 2015). Ako se procjene rade na osnovi valorizacije spomenutih komponenti, njihovo koreliranje s uspjehom na normativnim testovima znanja trebalo bi biti visoko. Međutim, u praksi je to drukčije, kao što pokazuju i dobiveni rezultati.

Suvremena didaktika ne daje apsolutnu prednost formativnom vrednovanju u odnosu na normativno. Tendencije su da je dominantno vrednovanje, zasnovano na međusobnom uspoređivanju učenika s obzirom na razine ostvarenja zadatka, jednakovrijedno kriterijskom vrednovanju koje je osnova za standard i definiranje kompetencija. Stoga je normativno vrednovanje uspostavljanje standarda koji bi trebali biti osnova za promatranje razvoja svakog učenika i definiranje kriterija za ocjenjivanje i samovrednovanje učenika (Gojkov, 2009).

U obrazovnim sustavima u kojima se razvila tradicija korištenja standardiziranih testova znanja postoje problemi jer postoje razlike između uobičajenih ocjena u školi i rezultata na testovima znanja (Duckworth i sur., 2012). Korelacije među njima su u rasponu od 0,62 do 0,66. Jedno od objašnjenja je to da objektivni testovi obrazovnoga postignuće mjere kompetencije potrebne u akademskom okruženju i šire, dok je za 
visoke ocjene u školi dovoljno zadovoljiti zahtjeve učitelja i programa (Šarčević i Vasić, 2014).

h) Utjecaj spola na kvalitetu znanja

Istraživanje je pokazalo da ne postoje statistički značajne razlike ni na jednoj razini znanja ni u cjelokupnom rezultatu (Tablica 6). Pokazalo se da su promjene u znanju između dječaka i djevojčica jednake i da ne utječu na njih. To podržava tezu da spol učenika ne utječe na promjenu u kvaliteti učenikova znanja kada je riječ o predmetu Priroda i društvo

Tablica 6.

Rana istraživanja (Brković, 1994) pokazala su da spol utječe na postignuće, ali neizolirano od ostalih faktora te da postoje razlike u usvajanju sadržaja kod učenika različitih spolova ovisno o nastavnom predmetu. Nedavno istraživanje pokazalo je da ne postoje značajne razlike u postignuću između dječaka i djevojčica. I dječaci i djevojčice bili su jednako uspješni ili neuspješni u školi što ovisi isključivo o drugim faktorima, a ne o spolu (Simić-Vukomanović i sur., 2012).

Međutim, danas postoje istraživanja koja pokazuju suprotno, odnosno koja tvrde da postoje razlike u školskom postignuću između dječaka i djevojčica. Većina istraživanja pokazala je da su djevojčice uspješnije od dječaka u školskom postignuću i u većini nastavnih predmeta (Krneta, 2000). Klasična objašnjenja takvih rezultata idu u smjeru osobina ličnosti i motivacije za učenje određenih nastavnih predmeta (Steinmayr i Spinath, 2008). Drugi autori tražili su objašnjenja za te razlike u drukčijim kognitivnim sposobnostima djevojčica i dječaka (Babarović i sur., 2010).

\section{Zaključak}

Kahoot je jednostavan i intuitivan mrežni alat za izradu kvizova kojima učenici mogu provjeriti svoje znanje i brzinu reakcije na atraktivan i zabavan način. On potiče kompetitivni duh učenika i tako povećava i motivaciju učenika. Rad analizira primjenu Kahoot kviza u poučavanju nastavnoga predmeta Priroda i društvo kod učenja osnovnih pojmova reljefa. Analiza rezultata pokazala je da su učenici koji su koristili Kahoot kviz imali bolji uspjeh u rezultatima od učenika koji su se poučavali na tradicionalni način. Primjena Kahoot kviza pomogla je učenicima da pokažu bolje znanje na razini prepoznavanja i analize. Njihovo cjelokupno znanje postalo je veće i kvalitetnije.

Rad zaključujemo tvrdnjom da su razine znanja u pozitivnoj korelaciji s vrednovanjem iz predmeta Priroda i društvo. Utjecaj vrednovanja je osrednji na razini prepoznavanja i reprodukcije te slabiji na razini analize i cjelokupnoga znanja. To potvrđuje da prethodno znanje učenika utječe na usvajanje novoga sadržaja. Dobiveni rezultati pokazali su da ne postoji razlika u uspjehu između dječaka i djevojčica. I dječaci i djevojčice bili su jednako uspješni na razini prepoznavanja, reprodukcije i analize. 